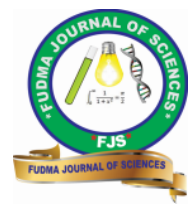

FUDMA Journal of Sciences (FJS)

ISSN online: $2616-1370$

ISSN print: 2645 - 2944

Vol. 4 No. 3, September, 2020, pp $708-720$

DOI: https://doi.org/10.33003/fjs-2020-0403-340

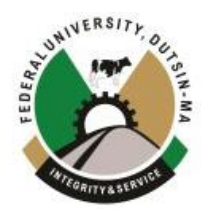

\title{
PERCEPTION OF HORTICULTURISTS ON NEMATODE PESTS OF ORNAMENTAL PLANTS AND THE LIKELIHOOD OF SOIL AS PRIMARY SOURCE OF INFECTION
}

\author{
*1Tanimola A. A., ${ }^{1}$ Nwokogba S. O. and ${ }^{2}$ Oladele A. T.
}

${ }^{1}$ Department of Crop and Soil Science, Faculty of Agriculture, University of Port Harcourt, Choba, Rivers State, Nigeria ${ }^{2}$ Department of Forestry and Wildlife Management, Faculty of Agriculture, University of Port Harcourt, Choba, Rivers State, Nigeria

*Corresponding Author's Email: tanimoladebo@yahoo.com,

\begin{abstract}
Nematode pests contribute significantly to poor growth and losses in ornamental plants. However, majority of ornamental garden operators have little or no knowledge of these nematode pests. This study assesses the perception of horticulturists on plant-parasitic nematodes (PPNs) of ornamental plants in Port Harcourt metropolis. A total of 23 ornamental gardens were randomly chosen and visited. Structured questionnaire was randomly administered directly to all operators in collection of data and options were given in code to rank the results. A total of fifty-three soil samples were collected from all the gardens visited. Nematode pests were extracted from the samples using standard procedures. Data were processed using descriptive statistics, diversity indices, relative importance value (RIV) and analysis of variance. The results showed that $95.7 \%$ of the horticulturists were male, $78.2 \%$ were youth, while $100.0 \%$ of the ornamental garden owners had no knowledge of nematode pests attacking ornamental plants. Four nematode pest genera, Meloidogyne, Pratylenchus, Tylenchulus and Helicotylenchus were found in the soil being used for propagation by these horticulturists. However, Meloidogyne species with the RIV of $40.45 \%$ were the most important genus and the most frequently encountered nematode pest (relative frequency of occurrence of 19.35\%). Hilltop horticultural garden had the highest mean population of PPNs, but not significantly more than PPNs in other gardens. The study revealed that nematode pests are one of the major bio constraints to ornamental plants and that soil if not treated could be a primary source of nematode infection.
\end{abstract}

Keywords: Meloidogyne species, Nematode pests, Ornamental gardens, Ornamental plants, Relative importance value.

\section{INTRODUCTION}

Beautification values of ornamental plants are one of the reasons facilitating their cultivation and they also enhance human health and provide other environmental benefits (Burchett et al., 2008; Altmann, 2015). These ornamental plants beside physical benefits do confer other advantages on mankind such as mental and physiological facilitating relaxation, stress relieve, air purifying agents and higher productivity level (Bourlakis et al., 2010). Globally, the significant and profitable contribution of ornamental plants industry to economy of nations has been acknowledged in which they encourage economic opportunities such as employment and revenue generation (Technavio, 2017). It has been projected that a revenue of approximately ninety-six billion dollars (\$US 96.4 billion) will be generated from the commercial and private uses of ornamental plants in the year 2021 (Technavio, 2017). Globally, The Netherlands, Kenya, Columbia, Malaysia, Ethiopia have been reported as major producers of ornamental plants (Rabobank, 2015). Nigerians are gradually becoming aware of the need for a beautiful, manageable and sustainable environment. The high intensity of a flourishing horticultural business in metropolitan centres attests to this fact. Kenya and Cote d' Ivoire are major exporters of cut flowers into the French market, yet Nigeria shows great promise in this trade. The great potentials identified in the production of ornamentals are being threatened during cultivation of these plants by bio-constraints like pests and diseases such as nematode pests.
Worldwide, nematode pests of plants contribute to the banes in the production of ornamental plants, but few of them cause significant problems (Sasser and Freckman, 1987; Deimi et al., 2008). They are implicated in chlorotic and stunted growth, smaller and fewer leaves and flowers, galling formation, root proliferation, poor response to fertilizers due to root damage, reduction in yield of ornamental plants, and ultimately death (Ibrahim and Al-Yahya, 2002; Rathour et al., 2003 and Tariq et al., 2007). Throughout the world, ornamental plants production suffers $11.1 \%$ losses attributed to plant-parasitic nematodes (Sasser and Freckman, 1987). Among the plant-parasitic nematodes, Meloidogyne species are responsible for the rootknot diseases and they cause serious damage to ornamental and foliage plants (Sasser and Freckman, 1987).

The root-knot nematodes, Meloidogyne species are the most cosmopolitan nematode pest and have been reported as key pests on ornamental plants in many regions of the world (Deimi et al., 2008; Brito et al., 2010; El-Sherbiny, 2011 and Meressa et al., 2014). Celosia argentea is being grown as an ornamental plant, but it is also consumed as a vegetable and pot-herb in many western African countries. Meloidogyne incognita and $M$. javanica readily attacked Celosia argentea and significantly reduced its growth (Caveness and Wilson, 1977). The reniform nematode, Rotylenchulus reniformis, the stunt nematode, Tylenchorhynchus spp., the lesion nematodes, Pratylenchus spp., the leaf nematode, Aphelenchoides spp. and the spiral nematode, Helicotylenchus spp. have been associated 
with the decline of some ornamental plants (Rashid and Azad, 2013; Al-Sayed et al., 2014).

The stem and bulb nematodes (Ditylenchus dipsaci and D. destructor), leaf and bud nematodes (Aphelenchoides ritzemabosi and $A$. fragariae) and root-lesion nematodes, Pratylenchus penetrans are also considered as key nematode pests infecting ornamental plants(Southey, 1993). Also, bulb and stem lesions caused by nematodes of the genus Ditylenchus (D. dipsaci Kuhn and D. destructor Thorne) have been reported in ornamental bulb plant species such Crocus, Hyacinth, Iris, Narcissus and Tulip grown in the Netherlands (Westeijn and De Rooy, 1974). Plant-parasitic nematodes form important groups of organisms found in the soil, roots and leaves of plants with a major effect on plant growth and production (Decraemer and Hunt, 2013). Most ornamental plants are grown by most horticulturists using the soil as the major medium. Several studies have examined roots and soils of ornamental plants after cultivation for nematode pests (Brito et al., 2010; Mahdavian and Jahanshahi, 2017). However, there is dearth of information on nematode pests in collected soils being used as one of the growing media for ornamental plants prior to cultivation. There is need to evaluate the knowledgestatus of horticulturists or ornamental garden operators on nematode pests of ornamental plants in Nigeria and to determine if the soil medium for cultivation is one of the major sources of nematode infection.

Floriculture is an input intensive agriculture and there has been less information provided on the distribution of nematode pests on ornamentals in Nigeria. This study was carried out to assess the knowledge-status of horticulturists or ornamental garden operators on nematode pests as one of the biotic threats to ornamental plants and to ascertain if soil as one of the growing media serves as a source of primary infection to ornamental plants.

\section{MATERIALS AND METHODS}

\section{Study Area}

A total of 23 ornamental gardens within Port Harcourt metropolis, Rivers State were randomly visited in the study. Rivers State occupies latitudes range $520^{\prime} 0^{\prime \prime} \mathrm{N}$ and $54^{\prime} 5^{\prime \prime} \mathrm{N}$, and longitudes range of $620^{\prime} 0^{\prime \prime} \mathrm{E}$ and $735^{\prime} 0^{\prime \prime} \mathrm{E}$. The State is characterised with tropical hot monsoon climate owing to its latitudinal position. Heavy rainfall from April to October ranging from $2000 \mathrm{~mm}$ to $2500 \mathrm{~mm}$ and high temperature throughout the year with relatively constant high humidity are associated features with this climate (Asimiea et al., 2015).

\section{Instrument for Data Collection}

A structured pre-tested and validated questionnaire by professionals in the Faculty of Agriculture, University of Port Harcourt (UNIPORT) was used in the collection of data from the commercial horticulturists, while interview was also used to collect data from illiterate respondents. The questionnaire centered on soil-borne disease challenges in commercial ornamental gardens and the demographic characteristic of the respondents.

\section{Survey Design, Sample Size and Sampling Technique}

Structured questionnaires were purposively administered among twenty-three different ornamental gardens. Options were given in code and used to rank the results provided by the respondents. Copies of the questionnaire were administered directly to all respondents by the researcher. The copies of the questionnaire were collected back from the respondents upon completion while oral interviews were conducted and responses recorded appropriately for illiterate respondents.

\section{Collection of Soil Samples}

Soil samples were collected from soil heaped for propagation of ornamental plants in the nursery section of each ornamental garden visited. Three (3) soil samples of $250 \mathrm{ml}$ each were collected using hand trowel, from the pool of each ornamental garden visited into polythene bags and well labelled. Soil samples collected were promptly moved in insulator boxes to the laboratory for further processing.

\section{Extraction of Plant-parasitic Nematodes from Soil Samples} The nematodes were extracted using pie-pan method of nematode extraction (Whitehead and Hemming, 1965). Soil was thoroughly mixed together after collection for removal of stones and other debris. Two hundred $\mathrm{ml}$ of sieved soil sample was taken and poured on a facial tissue in a plastic sieve followed by the addition of water to the extraction plates by the side. The set-up was left for 24 hours and the sieves were later removed. The nematode suspension in the plates was then transferred into a beaker and allowed to settle down and after settling, the water was poured into a sample bottle for identification.

Identification of Plant-parasitic Nematodes: The extracted plant-parasitic nematodes were identified as described by Dropkin (1980). The nematode-water suspension from soil was preserved by $4 \%$ of formaldehyde prior to identification and enumeration of the plant-parasitic nematodes. Aliquot of $2 \mathrm{ml}$ suspension was pipette into Doncaster counting dish (Doncaster, 1962). The counting dish was placed under a dissecting microscope and compound microscope synchronously for identification and counting using Bell's key (Bell, 2004). Multiple tally counters were used in the counting of the nematodes.

Data Analysis

Descriptive statistics were used to process data on frequency of occurrence of nematodes with these formulas (Norton, 1978);

$$
\text { Absolute Frequency of Occurrence }(F)=\frac{\text { No. of occurrence of species }}{\text { Number of samples collected }}
$$$$
\text { Relative Frequency of Occurrence }=\underline{\text { Frequency of a species }} \quad X \quad \underline{100 \%} \frac{1}{\text { Frequency of all species }}
$$

Nematode Abundance and Relative Importance Value

Nematode abundance and relative importance value of plant- parasitic nematode species were determined using the methods of Shukla and Chandel (2014) and Kent and Coker (1996) with 
modifications.

$$
\begin{gathered}
\text { Relative Density }=\frac{\text { Density of individual of species }}{\text { Total density of all species }}+\frac{100 \%}{1} \% \\
\text { Relative Importance Value }(\%)=\frac{\text { Relative Density }+ \text { Relative Frequency }}{2}
\end{gathered}
$$

Determination of Community Structure and Diversity of Nematode Communities

The Paleontological Statistical Tool (PAST) of Hammer et al. (2001) was used to determine the diversity of nematode communities. Some indices calculated were:

i. $\quad$ Genera $(\mathrm{G})$ or Species Richness $(\mathrm{S})$;

ii. Shannon-Wiener index $\left(\mathrm{H}^{\prime}\right):\left(\mathrm{H}^{\prime}\right)=-\sum$ (pi)(Inpi)

iii. Evenness index $(\mathrm{J})=\mathrm{H}^{\prime} / \mathrm{InS}$

Where, $\mathrm{S}=$ Number of species enumerated in the community.

iv. Dominance index: Dominance index $=\sum\left(\mathrm{n}_{\mathrm{i}} / \mathrm{n}\right)^{2}$

Data from nematode counts were transformed using Log10 $(\mathrm{x}+1)$, then analyzed with analysis of variance (ANOVA) and Fisher's Least Significant Difference was used to separate means at probability of 5\% with Statistical Analysis System (SAS, 2007) package

\section{RESULTS}

Demographic characteristics of horticulturists within Port Harcourt metropolis on knowledge of nematode pests of ornamental plants

The demographic characteristics found in the questionnaire administered to the ornamental plant garden owners within Port Harcourt metropolis showed that $30.4 \%$ of the horticultural gardens are located along Nigerian Television Authority (NTA) road and $21.7 \%$ on Ikwerre road and University of Port Harcourt (UNIPORT) gate (Table 1). $17.4 \%$ of the ornamental gardens are

located at Peter Odili road, while Ozuoba area had $4.3 \%$ of these gardens. In terms of the state of origin of the horticulturists/garden owners, 52.2\% of them hail from Akwa Ibom State, $17.4 \%$ are natives of Cross River and also $17.4 \%$ are Rivers State indigenes. Delta and Imo States have equal percentage of $4.3 \%$ each in terms of ornamental garden owners in Port Harcourt metropolis. The ornamental garden business in Port Harcourt is dominated by the indigenes of Akwa Ibom. Majority of the operators are youth $(78.2 \%)$ with age range of the horticulturists from 26 to 45 years. There are more male horticulturists $(95.7 \%)$ in the business than females $(4.3 \%)$ (Table 1).

In terms of the educational qualifications, $69.6 \%$ of the ornamental garden owners had secondary school education, $17.3 \%$ had primary school education while few (13\%) had tertiary level education (Table 1). Most of the ornamental garden owners $(87 \%)$ acquired their ornamental plant production training through apprenticeship; only $8.7 \%$ acquired theirs in a University or College of Agriculture, while $4.3 \%$ did not undergo any form of training (Table 1).
Information on the garden size and average income of the horticulturists within Port Harcourt metropolis

Table 2 showed the garden size and average income of horticulturists within Port Harcourt metropolis. 65.2 of the ornamental garden operators own a garden size of less than one plot $\left(17 \times 33 \mathrm{~m}^{2}\right)$ of land and $21.7 \%$ has ornamental garden size ranging from 1-5 plots. Also, $73.9 \%$ of the horticulturists have between 1-2 gardens, whereas $21.7 \%$ own about $3-4$ gardens (Table 2).

The average monthly income of the ornamental garden operators showed that majority $(43.5 \%)$ of them earn between $\$ 10,000-20,000$ per month and $13 \%$ of them earn average monthly income between $\$ 20,000$ - 50,000. For other sources of income, $73.9 \%$ of the horticulturists have no other source of income, but $4.7 \%$ are contractors, traders and artisans.

Knowledge of the horticulturists on nematode pests, other diseases and methods of pest management

Knowledge of the horticulturists on nematode pests, other diseases and methods of pest management is presented in Table 3. Majority of the horticulturists or garden owners $(60.9 \%)$ have no knowledge of pathogens causing diseases on their plants. Most of them (82.6\%) learnt about diseases of ornamental plants through experience. $95.7 \%$ of the garden owners uses agrochemicals in managing diseases, whereas only $4.3 \%$ uses natural products. None of the ornamental garden owners $(100 \%)$ had knowledge of plant-parasitic nematodes. Some of the horticulturists $(65.2 \%)$ indicated that they have training on pest management and $56.5 \%$ of them were trained in similar private gardens, while $4.3 \%$ indicated that they had their training from universities and research institutes and $39.1 \%$ indicated other sources of training (Table 3). Most of the ornamental garden owners or horticulturists (91.3) rely mainly on the use of Agrochemicals in the management of diseases and other pests in their gardens (Table 3).

Growing media being used by horticulturists/garden owners and other practices influencing infection by nematode pests

Most horticulturists (91.3\%) make use of topsoil in the propagation of ornamental plants and $8.7 \%$ of them make use of sawdust as the growing medium (Table 4). Table 4 also highlights that: 
Table 1: Demographic characteristics of horticulturists within Port Harcourt metropolis

\begin{tabular}{|c|c|c|}
\hline Variable & Frequency & Respondents (\%) \\
\hline \multicolumn{3}{|c|}{ Location of Garden } \\
\hline Ikwerre Road & 5 & 21.7 \\
\hline NTA Road & 7 & 30.4 \\
\hline Uniport Gate & 5 & 21.7 \\
\hline Ozuoba & 1 & 4.3 \\
\hline Peter Odili Road & 4 & 17.4 \\
\hline Others & 1 & 4.3 \\
\hline Total & 23 & 100.0 \\
\hline \multicolumn{3}{|c|}{ State of Origin of Operators } \\
\hline Akwa Ibom & 12 & 52.2 \\
\hline Cross-River & 4 & 17.4 \\
\hline Delta & 1 & 4.3 \\
\hline Rivers & 4 & 17.4 \\
\hline Imo & 1 & 4.3 \\
\hline Others & 1 & 4.3 \\
\hline Total & 23 & 100.0 \\
\hline \multicolumn{3}{|c|}{ Age of Garden Owners } \\
\hline Below 25 & 1 & 4.3 \\
\hline $26-35$ & 9 & 39.1 \\
\hline $36-45$ & 9 & 39.1 \\
\hline $46-55$ & 4 & 17.4 \\
\hline \multicolumn{3}{|c|}{ Gender of Operators } \\
\hline Male & 22 & 95.7 \\
\hline Female & 1 & 4.3 \\
\hline Total & 23 & 100.0 \\
\hline
\end{tabular}


Table 1 Cont'd: Demographic characteristics of horticulturists within Port Harcourt metropolis

\begin{tabular}{|c|c|c|}
\hline Variable & Frequency & Respondents (\%) \\
\hline \multicolumn{3}{|l|}{ Educational Qualification } \\
\hline Primary & 4 & 17.4 \\
\hline Secondary & 16 & 69.6 \\
\hline Tertiary & 3 & 13.0 \\
\hline Total & 23 & 100.0 \\
\hline \multicolumn{3}{|l|}{ Specialization } \\
\hline Other biological/sciences & 2 & 8.2 \\
\hline No response & 21 & 91.3 \\
\hline Total & 23 & 100.0 \\
\hline \multicolumn{3}{|l|}{ Where The Training Took Place } \\
\hline Apprenticeship & 20 & 87.0 \\
\hline University/Polytechnic/College & of & \\
\hline Agriculture & 2 & 8.7 \\
\hline No response & 1 & 4.3 \\
\hline Total & 23 & 100.0 \\
\hline
\end{tabular}


Table 2. Information on the garden size and average income of the horticulturists within Port Harcourt metropolis Items Frequency

Respondents (\%)

Garden Size

Less than 1 plot

15

65.2

1-2plots

5

21.7

3-5 plots

3

21.7

Total

100

Number of Garden(s)

$1-2$

3-4

Above 4

Total

Source of Income

Artisan

Trading

Contractor/Supply

Others

None

Total

Average monthly income

Below 10,000

10,000-20,000

20,000-30,000

40,000-50,000

Above 50,000

Total
17

5

1

23

1

2

1

17

23

3

10

3

3

23
73.9

21.7

4.3

100

8.7

4.3

8.7

4.3

73.9

100.0

13.0

43.5

13.0

13.0

17.4

100.0 
Table 3: Knowledge of the horticulturists on nematode pests, diseases and methods of pest management

\begin{tabular}{lll}
\hline Items & Frequency & Respondents $(\%)$ \\
\hline Organism causing Diseases? & 9 & 39.1 \\
Yes & & 60.9 \\
No & 14 & 100
\end{tabular}

Knowledge

Experience

Common Organisms

Asking others

Total

\section{Treatment of Diseases}

Use of agrochemicals

Use of naturals/Plant extracts

\section{Knowledge of Nematode Pests}

No

\section{Training on Pest Management}

Yes

No

Total
Others

Total

\section{Type of Treatment}

\author{
Agrochemical
}

Cultural method

Total

$\begin{array}{ll}21 & 91.3 \\ 2 & 8.7 \\ 23 & 100.0\end{array}$

65.2

34.8

100.0

56.5

4.3

39.1

100.1

while $34.8 \%$ treat their soil.

Entries in Table 4 shows that $21.7 \%$ of the horticulturists treat their soils through heat sterilization, but others (17.4\%) make

use of chemical treatments. Physical appearance of the soil is

$78.3 \%$ of soil being used by the horticulturists are bought from ornamental garden operators $(65.2 \%)$ indicated that they do not treat their soil against pests and pathogens before being used, 
being used by $87 \%$ of the horticulturists in the choice of soil propagation, while $4.3 \%$ make use of soil nutrient test and $8.7 \%$ make use of other method for choice of soil propagation method. All the ornamental garden owners acknowledged that they do not carry out any laboratory test before using their soils (Table 4).

Occurrence and relative importance value of plant parasitic nematodes in the soil of ornamental gardens

Figure 1 shows the occurrence and relative importance value of plant-parasitic nematodes in ornamental garden soils within Port Harcourt metropolis. Meloidogyne species with relative frequency of occurrence (RFOC 19.35\%) was the most frequently encountered nematode pests and the most important (according to relative importance value (RIV of $40.45 \%$ ) in the soils of ornamental gardens in Port Harcourt metropolis. This was followed by Tylenchulus species and then Helicotylenchus species (Fig. 1).

Diversity of Plant-Parasitic Nematodes found in the Soils of Ornamental Gardens in Port Harcourt Metropolis

Table 5 shows the diversity of plant-parasitic nematodes found in the soils of ornamental gardens in Port Harcourt metropolis.
The mean plant-parasitic nematode individuals encountered in the soils was 12.63 , with a Dominance index of 0.42 while the Shannon Weiner index was 1.13. The Evenness index of 0.62 was obtained for the plant-parasitic nematodes associated with ornamental garden soils.

Population of Plant-Parasitic Nematodes found in the Soils of the Ornamental Gardens within Port Harcourt Metropolis

Table 6 shows the mean population of plant-parasitic nematodes in the soils of ornamental gardens in Port Harcourt metropolis. Hiltop horticultural gardens had the highest mean plant-parasitic nematodes in the soils of their garden, but this was not significantly higher than population of plant-parasitic nematodes in soils of most of the horticultural gardens. Isinimi, Oguta and Prince horticultural gardens had no plant-parasitic nematodes in their soils (Table 6). 
Table 4: Growing media being used by horticulturists and other practices influencing infection by nematode pests

Variable Frequency Respondent (\%)

Growing Media

Topsoil

Sawdust

Total

Source of Soil

Buy from suppliers

18

Dig from surroundings

5

23

Treatment of Soil

Yes

No

Total

Method of Treatment

Sterilized by heating

Chemical Treatment

Total

Choice of Soil for Propagation

Physical appearance of soil

Soil Nutrient test

Others

Total

Soil Test

No

Yes
8

15
78.3

21.7

100.0

91.3

8.7

100.0

34.8

65.2

100.0

21.7

17.4

100.0

87.0

4.3

8.7

100.0

100.0

0 


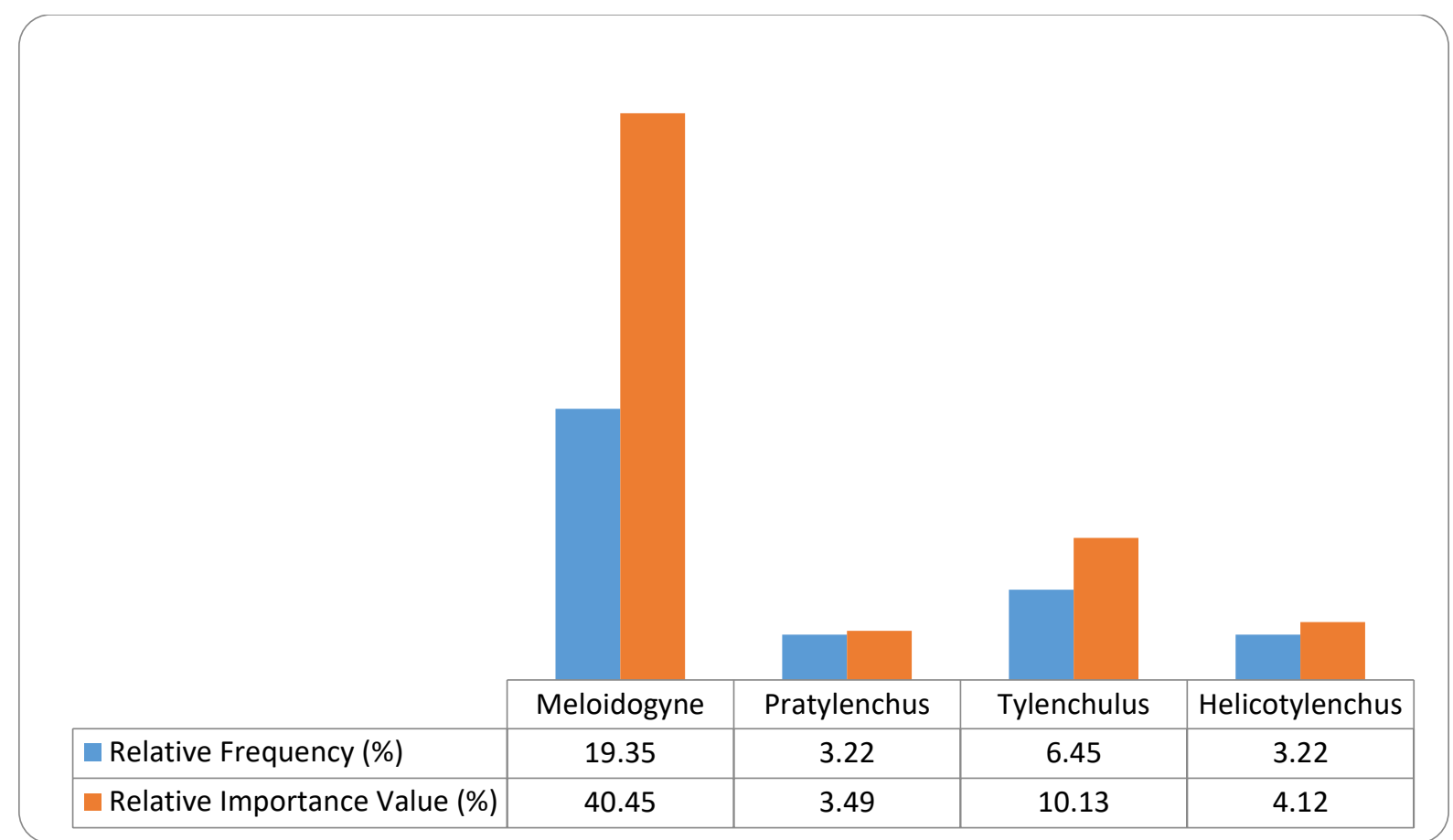

Figure 1: Occurrence and relative importance value of plant-parasitic nematodes in the soil of ornamental gardens in Port Harcourt metropolis

Table 5: Diversity of plant-parasitic nematodes found in the soil of ornamental gardens in Port Harcourt metropolis Diversity Indices Values

Individual

Dominance

12.63

Simpson

0.42

Shannon

0.57

Evenness

1.13

0.62 
Table 6: Population plant-parasitic nematodes in nursery soils of ornamental gardens in Port Harcourt Metropolis Ornamental gardens Mean population of nematode pests

\begin{tabular}{|c|c|}
\hline Hilltop horticultural garden & $50(1.64)$ \\
\hline I.k horticultural garden & $26.67(0.63)$ \\
\hline Bliss horticultural garden & $20(1.32)$ \\
\hline Godwin horticultural & $16.67(0.56)$ \\
\hline Kaades horticultural garden & $13.33(0.84)$ \\
\hline Ben Green horticultural garden & $20(0.99)$ \\
\hline Goodland horticultural garden & $10(0.78)$ \\
\hline God's favour horticultural garden & $6.67(0.9)$ \\
\hline Fruitful horticultural garden & $3.33(0.34)$ \\
\hline Land of beauty horticultural garden & $0.00(0.00)$ \\
\hline Dominion horticultural garden & $6.67(0.44)$ \\
\hline Isinimi horticultural garden & $0.00(0.00)$ \\
\hline Edduko parks and gardens & $3.33(0.34)$ \\
\hline Laritex horticultural garden & $13.33(0.84)$ \\
\hline Blessed horticultural garden & $13.33(0.88)$ \\
\hline Oguta horticultural garden & $0.00(0.00)$ \\
\hline Prince horticultural garden & $0.00(0.00)$ \\
\hline Solution horticultural garden & $10(0.78)$ \\
\hline Sunny royal horticultural garden & $10(0.49)$ \\
\hline $\operatorname{LSD}(\mathbf{P} \leq \mathbf{0 . 0 5})$ & $26.66(1.024$ \\
\hline
\end{tabular}

$($ ) $=$ logarithm transformed

\section{DISCUSSION}

According to the survey in the study area (Port Harcourt metropolis), it was observed that there are more males in the ornamental garden business than females and this observation has been attributed to the arduous nature of ornamental plant business. This finding is in line with the reports of Adeduntan (2015) and Akintoye et al. (2018) that males dominate the ornamental industry in southwestern Nigeria because of the labour intensiveness of the business. In the assessment of ornamental nursery operation in Akwa Ibom State, Nigeria, Nelson et al. (2018) also reported that males dominate the ornamental garden business compared to female little or no presence.

From the demographic characteristics data entries, majority of the garden operators were predominantly youth and this contributes to their agility and capability to make good production decisions which brings about high productivity. The labour-intensive nature of the ornamental industry is one of the reasons for youth dominance of the industry. Akintoye et al. (2018) also reported the dominance of the youth in the ornamental industry in the Southwest Nigeria in support of the outcome in this study.

None of the ornamental garden operator has any knowledge on nematode pests attacking their stocks and this is because nematode pests are not visible to the naked eyes for easy diagnosis. They are microscopic which makes it difficult for horticulturists to see these nematodes thereby limiting their knowledge. Also, the symptoms nematode pests produce might be non specific and hidden, thus limiting right diagnosis that would have facilitated effective management (Lopes-Caitar et al., 2019). Poor training among the operators on pest management owing to lack of formal education support the poor identification of nematode pests as one of the major constraints to production of ornamental plants. Many workers have reported poor knowledge of nematode pests as one of the major pests of ornamental plants (Lopes-Caitar et al., 2019)

This study reveals that Meloidogyne is the most frequent nematode genus found in the soils of most ornamental gardens in Port Harcourt metropolis. Several other workers have reported Meloidogyne species with over 100 species as one of the key nematode pests of ornamental plants (Elling, 2013; Lopes-Caitar et al., 2019). Stunted growth and loss of aesthetic values due to chlorosis, wilting and leaf margin necrosis have been reported in landscape plants infected with plant-parasitic nematodes particularly root-knot nematodes (Sharma and Rich, 2005). Root-knot nematodes limit productivity by damaging 
numerous nursery crops directly and by forming disease complexes with certain soil-borne fungal pathogens (Walker et al., 1994; Zarina and Abid, 1995). Also other nematode pests such as Pratylenchus, Tylenchulus and Helicotylenchus reported in this study have been identified as damaging on ornamental plants (Lopes-Caitar et al., 2019).

\section{CONCLUSION}

Commercial production of ornamental plants provides family income for many in Port Harcourt metropolis. However, most horticulturists or ornamental garden owners have no knowledge of nematode pests damaging these plant species. The study showed that soil as one of the growing media if not treated is a major source of infection of ornamental plants by nematode pests. Horticulturists or ornamental garden operators should be adequately trained on nematode pests of ornamental plants and proper treatments of soils being used in cultivation should be carried out to manage them so as not to be source of infection for nematodes and other pathogens.

\section{REFERENCES}

Adeduntan, S.A. (2015). Contribution of some ornamental plants to the socio-economic development of urban household in Akure metropolis. African Journal of Agricultural Research 10(4):264-C268.

Akintoye, H. A., Layade, A. A., Aina, O. O., Adebayo, A. G., Shokalu, A. O., Olatunji, M. T., Akinkunmi, O. Y., Oyedeji, E. O., Igberaese, P. O., Fade-Aluko, A. A., James, I. E. and Okoyo, M. E. (2018). Profitability of Ornamental Plants Production in Southwest, Nigeria Proceedings of the 36th Annual Conference of Horticultural Society of Nigeria (Hortson), Lafia 2018 Faculty of Agriculture Shabu-Lafia Campus, Nasarawa State University, Keffi, Nasarawa State, Nigeria.

Al-Sayed, A.A., Abdel-Rahman, A.A. and Kesba, H. H. (2014) Phytonematode community structure and dynamics on ornamental plantations of Egypt. Egyptian Journal of Agronematology, 13(1): 26-43.

Altmann, M. (2015). Developments and trends in the flower and plant market for 2015/ 2016. Retrieved from http://www.intracen.org/uploadedFiles/intracen.org/Content/Ex porters/Market_Data_and_Information/Market_information/M arket_Insider/Floriculture/Developments and trends in the flower and plant market for 2015 - 2016.pdf

Asimiea, A. O., Tanimola, A. A. and Bob-Manuel, B. P. (2015). Nematode pests of cassava (Manihot esculenta Crantz) in three Local Government Areas of Rivers State in Nigeria. Journal of Applied Science and Agriculture: 10 (6): 68-77

Bourlakis, M., Tzavaras, M. and Tzimitra-Kalogianni, I. (2010). Consumer behaviour in the Greek. British Food Journal, 403-415. Retrieved from http://www.emeraldinsight.com/doi/pdfplus/10.1108/00070701 011034411

Brito, J. A. R., Kaur, R., Cetintas, J. D., Stanley, M. L., Mendes, T., Powers, O. and Dickson. D.W. (2010). Meloidogyne species infecting ornamental plants in Florida
Nematropica 40:87-103.

Burchett, M., Torpy, F. and Tarran, J. (2008). Interior plants for sustainable facility ecology and workplace productivity. Plants and Indoor Environmental Quality Group, 7-9. Retrieved from http://www.wsindoorplants.com.au/articles/Interior-plants-andworkplace-producivity.pdf.

Caveness, F.E. and Wilson, G.F. (1977). Effect of root-knot nematodes on growth and development of Celosia argentea L. Acta Horticulturae 53, 71-74 https://doi.org/10.17660/ActaHortic.1977.53.8

Decraemer, W. and Hunt, D.J. (2006). Structure and classification. In: Perry, R.N. and Moens, M. (eds.), plant nematology, CABI publishing, Oxfordshire, UK, pp. 3 - 32

Deimi, A. M., Chitambar, J.J. and Maafi, Z.T. (2008). Nematodes associated with flowering ornamental plants in Mahallat, Iran. Nematologia Mediterranea, 36:115-123.

Doncaster, C. C. (1962). A counting dish for nematodes. Nematologica 7: 33 - 36 .

Dropkin, V.H. (1980). Recovery of nematode from infected roots by maceration. Nematologica, 5: 285-288.

Elling, E. A. (2013). Major emerging problems with minor Meloidogyne species. Phytopathology, 103(11):1092-102. doi: 10.1094/PHYTO-01-13-0019-RVW.

El-Sherbiny, A. A. (2011). Phytoparasitic nematodes associated with ornamental shrubs, trees and palms in Saudi Arabia, including new host records. Pakistan Journal of Nematology, 29 (2):147-164.

Hammer, O., Harper, D.A.T. and Ryan, P. D. (2001). PAST: Paleotological statistic software package for education and data analysis. Paleontological Electronica 4(1): 9 pp

Ibrahim, A. A. M., and Al-Yahya. F. A. (2002). Phytoparasitic nematodes associated with ornamental plants in Riyadh region, central Saudi Arabia. Alexandria Journal of Agricultural Research 47:157-167.

Kent, M. and Coker, P. (1996). Vegetation description and analysis. A practical approach. John Wiley and Sons, NY, pp 363

Lopes-Caitar, V.S., Pinheiro, J. B. and Marcelino-Guimarães, F. C. (2019). Nematodes in Horticulture: An Overview. Journal of Horticultural Science and Crop Research 1(1): 106-117

Meressa, B., Dehne, H. and Hallmann, J. (2014). Host Suitability of cut-flowers to Meloidogyne spp. and population dynamics of $\mathrm{M}$. hapla on the rootstock Rosa corymbifera'Laxa'. American Journal of Experimental Agriculture 4(11): 1397-1409.

Nelson, I. U., Udo, E. S. and Jacob, D. E. (2018). Profitability of ornamental plant business in

Akwa Ibom State, Nigeria. Eurasian Journal of Forest Science, 6(1): 35-43 
Norton, D.C. (1978). Ecology of plant-parasitic nematodes. John Wiley and Sons Inc., USA,

$$
268 \mathrm{pp}
$$

Rabobank. B. (2015). Rabobank Industry Note. Retrieved December 12, 2017, from www.rabobank.com:https://www.rabobank.com/en/images/Wor ld Floriculture Map 2015 vanRijswick Jan2015.pdf

Rashid, A. and Azad, S.A. (2013). Studies on the pathogenicity of Helicotylenchus dihystera on Celosia cristata. Indian Journal of Scientific Research 4(1): 153-154.

Rathour, K.S., Sharma, S. and Ganguly, S. (2003). Phytonematode communities associated with perennial ornamental and medicinal plants in Bareilly District, Uttar Pradesh. Proceedings of National Symposium on Biodiversity and Management of Nematodes in Cropping Systems for Sustainable Agriculture, Jaipur, India, 11-13 November, 2002. 31-38.

SAS. (2007). Statistical Analysis System User's Guide. SAS Institute Inc. Carry N.C. USA.

Sasser, J.N. and Freckman, D.W. (1987). A world prospective in Nematology: The role of Society. In: Vistae on Nematology Eds. Veech, J.A. and Dickson, D.W. Society of Nematologists Inc. Hyattsville, M.O. pp. 7-14.

Mahdavian, S. E. and Jahanshahi, F. (2017). Root knot nematode in ornamental plants of Mazandaran Province North of Iran. International Journal For Research In Agricultural And Food Science, 3(12):8-14 (ISSN: 2208-2719)

Sharma, J. and Rich, J.R. (2005). Host status of woody ornamental plants native to Southeastern U.S.A to three Meloidogyne species. Nematropica 35: 23-30.

Shukla, R. S. and Chandel, P. S. (2014). A textbook of plant ecology including ethnobotany and soil science. S. Chand and
Company Limited. India 512 pp

Southey, J. F. (1993). Nematode pests of ornamental and bulb crops. Pp.463-500 in K. Evans,

D. L. Trudgill, and J. M. Webster eds. Plant parasitic nematodes in temperate agriculture. Wallingford, UK: CAB International.

Tariq, M., Firoza, K. and Shahina, F. (2007). Medicinal plants as new hosts of root-knot and other nematodes from Hamdard University, Karachi, Pakistan. Pakistan Journal of Nematology 25(1): 165-172.

Technavio. (2017). Top 3 Emerging trends impacting the global flower and ornamental Plants market from 2017-2021:

Technavio. Retrieved December 12, 2017, from Technavio: https:/www.businesswire.com/news//home/20170322005811/e $\mathrm{n}$ /Top-3-Emerging-Trends-Impacting-Global-Flower

Walker, J.T. Melin, J.B. and Davis, J. (1994). Sensitivity of bedding plants to southern root-knot nematode, Meloidogyne incognita race 3. Journal of Nematology, 26(4 S): 778-781. Wiley and Sons, NY, pp 363

Westeijn, G, and De Rooy, M. (1974). Control of soil-borne fungi and nematodes parasitic to

ornamental bulbous crops in the Netherlands with special reference to soil disinfestation. Agriculture and Environment, $1: 237-242$

Whitehead, A.G. and Hemming, J.R. (1965). A comparison of some qualities, methods of extraction of small vermiform nematodes from the soil. Annals of Applied Biology, 55:25-38

Zarina, B. and Abid. M. (1995). New host records of root-knot nematodes (Meloidogyne species) in Pakistan. Pakistan Journal of Nematology, 13:49-50.

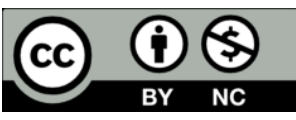

(C)2020 This is an Open Access article distributed under the terms of the Creative Commons Attribution 4.0 International license viewed via https://creativecommons.org/licenses/by/4.0/ which permits unrestricted use, distribution, and reproduction in any medium, provided the original work is cited appropriately. 